\title{
Experimental central composite design-based dispersive liquid-liquid microextraction for HPLC-DAD determination of diazinon in human urine samples: method development and validation
}

\author{
Reza Mohammadzaheri ${ }^{1,2}$, Mehdi Ansari Dogaheh ${ }^{3}$, Maryam Kazemipour ${ }^{1,2}$, and \\ Kambiz Soltaninejad ${ }^{4}$ \\ ${ }^{1}$ Department of Chemistry, Science and Research Branch, Islamic Azad University, Kerman, Iran \\ ${ }^{2}$ Department of Chemistry, Kerman Branch, Islamic Azad University, Kerman, Iran \\ ${ }^{3}$ Department of Pharmaceutics, Faculty of Pharmacy, Kerman University of Medical Sciences, Kerman, Iran \\ ${ }^{4}$ Department of Forensic Toxicology, Legal Medicine Research Center, Legal Medicine Organization, Tehran, Iran
}

[Received in May 2019; Similarity Check in May 2019; Accepted in February 2020]

\begin{abstract}
Diazinon poisoning is an important issue in occupational, clinical, and forensic toxicology. While sensitive and specific enough to analyse diazinon in biological samples, current methods are time-consuming and too expensive for routine analysis. The aim of this study was therefore to design and validate a simple dispersive liquid-liquid microextraction (DLLME) for the preparation of urine samples to be analysed for diazinon with high performance liquid chromatography with diode-array detector (HPLC-DAD) to establish diazinon exposure and poisoning. To do that, we first identified critical parameters (type and volume of extraction and disperser solvents, $\mathrm{pH}$, surfactant, and salt concentrations) in preliminary experiments and then used central composite design to determine the best experimental conditions for DLLME-HPLC-DAD. For DLLME they were $800 \mu \mathrm{L}$ of methanol (disperser solvent) and $310 \mu \mathrm{L}$ of toluene (extraction solvent) injected to the urine sample rapidly via a syringe. The sample was injected into a HPLC-DAD $\left(\mathrm{C}_{18}\right.$ column, $250 \times 4.6 \mathrm{~mm}, 5 \mu \mathrm{m})$, and the mobile phase was a mixture of acetonitrile and buffer $(63: 37 \mathrm{v} / \mathrm{v}, \mathrm{pH} 3.2$; flow rate: $1 \mathrm{~mL} /$ $\mathrm{min})$. Standard calibration curves for diazinon were linear with the concentration range of $0.5-4 \mu \mathrm{g} / \mathrm{mL}$, yielding a regression equation $\mathrm{Y}=0.254 \mathrm{X}+0.006$ with a correlation coefficient of 0.993 . The limit of detection and limit of quantification for diazinon were $0.15 \mu \mathrm{g} / \mathrm{mL}$ and $0.45 \mu \mathrm{g} / \mathrm{mL}$, respectively. The proposed method was accurate, precise, sensitive, and linear over a wide range of diazinon concentrations in urine samples. This method can be employed for diazinon analysis in routine clinical and forensic toxicology settings.
\end{abstract}

KEY WORDS: disperser solvent; extraction solvent; high performance liquid chromatography; liquid phase microextraction; Taguchi orthogonal array

Diazinon (O,O-diethyl O-[4-methyl-6-(propan-2-yl) pyrimidin-2-yl] phosphorothioate) is one of the most common causes of occupational, clinical, and forensic organophosphate (OP) poisoning in the world (1-14). In biological samples it can be determined with several analytical methods for experimental, clinical, and forensic purposes (15-18), such as solid-phase extraction (SPE) followed by gas chromatography/mass spectrometry (GC/ MS) in postmortem blood samples (15), high performance liquid chromatography with diode-array detector (HPLCDAD) in serum and urine of patients with acute poisoning (16), or liquid chromatography with tandem MS in gastric content and blood for forensic toxicology (18).

Corresponding author: Dr Kambiz Soltaninejad, Department of Forensic Toxicology, Legal Medicine Research Center, Legal Medicine Organization, Behesht Street, Tehran-1114795113, Iran

E-mail:kamsoltaninejad@gmail.com
Although these methods are sensitive, and specific enough to analyse diazinon in biological samples, they are too time-consuming and expensive for routine analysis. This issue has called for the development of simple, fast, low-cost, user- and environment-friendly sample preparation methods such as liquid phase microextraction (LPME), which requires a small volume of a water-immiscible solvent (19).

One of the LPME methods is the so called dispersive liquid-liquid microextraction (DLLME). It is rapid, simple, inexpensive, efficient, and requires minimal (microlitre) volumes of low- and high-density solvents for the extraction of many water-based samples $(20,21)$.

However, to obtain optimal efficiency (20-22), this method has to be fine-tuned through trial and error, which is time-consuming, or through statistical models and experimental designs, such as the Taguchi orthogonal array design and central composite design $(\mathrm{CCD})(23,24)$. 
The aim of this study was to make use of experimental design and develop a fast, simple, inexpensive and specific DLLME-HPLC-DAD method for the determination of diazinon in human urine samples for routine analysis in clinical and forensic toxicology laboratories.

\section{MATERIALS AND METHODS}

\section{Chemicals}

HPLC-grade methanol, acetonitrile, water, toluene and dichloromethane were purchased from Merck Chemical Co. (Darmusdat, Germany). HPLC-grade standards for diazinon, pirimiphos-methyl, azinphos-ethyl, and chlorpyrifos were purchased from Dr. Ehrenstofer $\mathrm{GmbH}$ (Augsburg, Germany). All other chemicals and reagents were of analytical grade, purchased from Merck Chemical Co.

\section{Instrumentation and chromatographic conditions}

Separation, identification, and quantification were carried out on a Knauer HPLC system (Smartline Series 1200, Berlin, Germany). Chromatography was run isocratically on a Nucleosil ${ }^{\circledR} \mathrm{C}_{18}$ analytical column $\left(250 \times 4.6 \mathrm{~mm}, 5 \mu \mathrm{m}\right.$ particle size, Perfectsi ${ }^{\circledR}$ Target $)$. An RP-18 guard column was fitted upstream of the analytical column. The mobile phase was a mixture of acetonitrile and buffer, optimised (63:37 v/v, pH 3.2) and delivered by a Knauer 1050 HPLC pump at a flow rate of $1 \mathrm{~mL} / \mathrm{min}$. A diode array detector (K-2800, Knauer) with a wavelength range of 190-740 nm was used for detection. The system was equipped with ChromGate ${ }^{\circledR}$ software (version 3.3.2., Knauer).

\section{Sample preparation}

We used diazinon-free urine samples provided by healthy volunteers in our laboratory. They were kept frozen at $-20{ }^{\circ} \mathrm{C}$ until analysis and then thawed to room temperature. Each sample was added $10 \mu \mathrm{L}$ of pirimiphosmethyl (internal standard, IS) $(2.5 \mu \mathrm{g} / \mathrm{mL})$ and vortexed at $1250 \mathrm{xg}$ for $10 \mathrm{~min}$. Then we added $100 \mu \mathrm{L}$ of sodium lauryl sulphate (SLS) $(3 \% \mathrm{w} / \mathrm{v})$ and $100 \mu \mathrm{L}$ of sodium chloride $(\mathrm{NaCl})(1 \%, \mathrm{w} / \mathrm{v})$ to the glass tubes containing $1000 \mu \mathrm{L}$ of urine. The final solution was then prepared following the DLLME procedure.

\section{DLLME procedure}

A mixture of $800 \mu \mathrm{L}$ of methanol (disperser solvent) plus $310 \mu \mathrm{L}$ of toluene (extraction solvent) was quickly injected to the samples with a syringe (Hamilton, NV, USA), which dispersed fine droplets of toluene to form a cloudy solution. Over just a few seconds, the analytes were extracted on toluene droplets and after centrifugation at $1250 \mathrm{x} g$ for $15 \mathrm{~min}$, these droplets became a supernatant on the surface of the conical test tube. The supernatant phase was then completely transferred into another conical test tube and the residue dried by evaporation with nitrogen in a water bath, dissolved to a mobile phase, and then $20 \mu \mathrm{L}$ of the sample injected into the HPLC.

\section{DLLME optimisation with experimental design}

To achieve maximum recovery, the selection of extraction efficiency variables was based on preliminary experiments that yielded distinct responses of eight variables on three levels of experimental designs (Table 1). Optimisation was performed on spiked samples.

\section{Preparation of standard solutions}

Standard solutions were prepared by serially diluting the diazinon stock solution $(100 \mu \mathrm{g} / \mathrm{mL})$ with HPLC-grade water to $0.5,1.0,1.5,2,2.5,3$, and $4 \mu \mathrm{g} / \mathrm{mL}$. The stock solution $(2.5 \mu \mathrm{g} / \mathrm{mL})$ of pirimiphos-methyl (IS) in methanol was prepared and stored at $-20{ }^{\circ} \mathrm{C}$. The stock and standard solutions were prepared on a daily basis and stored in the dark at $4{ }^{\circ} \mathrm{C}$. All solutions were used on the day they were prepared.

\section{Experimental design}

To obtain optimal conditions, we relied on the fourfactor-two-level central composite design (CCD), which is used in response surface methodology. Briefly, each numeric factor is varied over five levels: plus and minus alpha (axial points), plus and minus 1 (factorial points), and the centre point. If categorical factors are added, CCD will be duplicated for every combination of the categorical factor

Table 1 Variables and their levels for experimental design

\begin{tabular}{lcccc}
\hline Symbol & Level 3 & Level 2 & Level 1 & Factor \\
\hline A & & methanol & acetonitril & type of disperser solvent \\
\hline B & & 10 & 0 & sonication duration $($ minute) \\
\hline C & dichloromethane & chloroform & toluene & type of extraction solvent \\
\hline D & 600 & 300 & 100 & volume of extraction solvent $(\mu \mathrm{L})$ \\
\hline E & 1000 & 500 & 0 & volume of disperser solvent $(\mu \mathrm{L})$ \\
\hline F & 5 & 3 & 1 & surfactant concentration $(\% \mathrm{w} / \mathrm{v})$ \\
\hline G & 5 & 3 & 1 & salt concentration $(\% \mathrm{w} / \mathrm{v})$ \\
\hline H & 10 & 7 & 4 & $\mathrm{pH}$ \\
\hline
\end{tabular}


levels. It was also used to investigate parabolic interactions between the following parameters: volume of extraction solvent (toluene), salt percentage $(\mathrm{NaCl})$, surfactant percentage (SLS), and the volume of disperser solvent (methanol). This CCD design allowed modelling the response surface by fitting a second-order polynomial with the number of experiments equal to 21 for four factorial designs at five levels and five replicated points. Table 2 shows the range of independent variables used in this study in terms of actual and coded values.

\section{HPLC method validation}

Validation included the following parameters: linearity, precision, accuracy, limits of detection and quantification, and selectivity (25). For calibration we used seven concentrations ranging from 0.5 to $4 \mu \mathrm{g} / \mathrm{mL}$ of diazinon. Each concentration was prepared in triplicate and analysed three times. Calibration curves were constructed by plotting the concentration of compounds versus peak area response. The linearity was evaluated with the least square regression method.

The limit of quantification (LOQ) was determined during the evaluation of the linear range of calibration curve. its actual concentration. The accuracy was expressed with recovery percentage.

Selectivity was evaluated by comparing chromatograms of different batches of urine spiked with diazinon, IS, tramadol, azinphos-ethyl, pirimiphos-methyl, and chlorpyrifos.

\section{Data analysis}

For regression analysis and diagram plotting for the experimental results we used the Design Expert v. 7.01 software (Stat-Ease Inc., Minneapolis, MN, USA).

\section{Ethical approval}

This project was approved by the Ethics Committee of the Legal Medicine Research Centre.

\section{RESULTS AND DISCUSSION}

\section{Results of DLLME optimisation}

Sonication and $\mathrm{pH}$ had negative effects on maximum recovery $(\mathrm{p}>0.05)$. Other parameters had a positive effect $(p<0.05)$ and were selected for further optimisation

Table 2 Analysis of variance for the proposed model

\begin{tabular}{lccccc}
\hline Source & Sum of Squares & df & Mean square & F value & p-value* Prob. $\mathbf{F}$ \\
\hline Model & 6195.89 & 14 & 442.56 & 41.69 & 0.0053 \\
\hline A & 2223.78 & 1 & 2223.77 & 206.49 & 0.0007 \\
\hline B & 72.231 & 1 & 72.31 & 6.81 & 0.0797 \\
\hline C & 726.08 & 2 & 363.04 & 34.2 & 0.0086 \\
\hline D & 862 & 2 & 431 & 40.6 & 0.0067 \\
\hline F & 229.05 & 2 & 114.52 & 10.79 & 0.0426 \\
\hline G & 1029.91 & 2 & 514.95 & 48.51 & 0.0052 \\
\hline H & 915.54 & 2 & 457.77 & 43.12 & 0.0062 \\
\hline Residual & 137.22 & 2 & 68.61 & 6.46 & 0.0817 \\
\hline Correction Total & 31.85 & 3 & 10.62 & & \\
\hline all p-values are statistically significant & 6227.774 & 17 & & &
\end{tabular}

The limit of detection (LOD) and LOQ were calculated as follows:

$\mathrm{LOD}=3.3 \sigma / \mathrm{S}$, and

$\mathrm{LOQ}=10 \sigma / \mathrm{S}$,

where $\sigma$ is the standard deviation of response, and $\mathrm{S}$ is the slope of the calibration curve.

The method's precision was determined by repeatability (intra-day) and intermediate precision (inter-day) and was expressed as relative standard deviation (RSD). Five replicate injections of diazinon standard solutions were prepared at concentrations ranging from 0.5 to $4 \mu \mathrm{g} / \mathrm{mL}$. The intra-day variation was assessed on the same day, while inter-day precision encompassed three consecutive days. Both assessments were carried out by the same analyst.

The accuracy of the method was tested with five replicates of three samples containing different diazinon concentrations, and the measurements were compared with
(Table 3). Methanol (as disperser solvent) and toluene (as extraction solvent) had positive effects on all variables and were used in the experiments.

\section{Response surfacing based on $C C D$}

The actual and statistically predicted diazinon recoveries for experiments are shown in Table 4, while Figure 1 shows

Table 3 Experimental ranges and levels of independent variables for the central composite design

\begin{tabular}{lccccccc}
\hline & & & $\boldsymbol{\alpha -}$ & $\mathbf{1 -}$ & $\mathbf{0}$ & $\mathbf{1 +}$ & $\boldsymbol{\alpha +}$ \\
\hline Methanol & $\mu \mathrm{L}$ & $\mathrm{A}$ & 200 & 400 & 600 & 800 & 1000 \\
\hline $\mathrm{NaCl}$ & $\%$ & $\mathrm{~B}$ & 0 & 1 & 2 & 3 & 4 \\
\hline $\mathrm{SLS}$ & $\%$ & $\mathrm{C}$ & 0 & 1 & 2 & 3 & 4 \\
\hline Toluene & $\mu \mathrm{L}$ & $\mathrm{D}$ & 225 & 300 & 375 & 450 & 525
\end{tabular}

SLS - sodium lauryl sulphate 


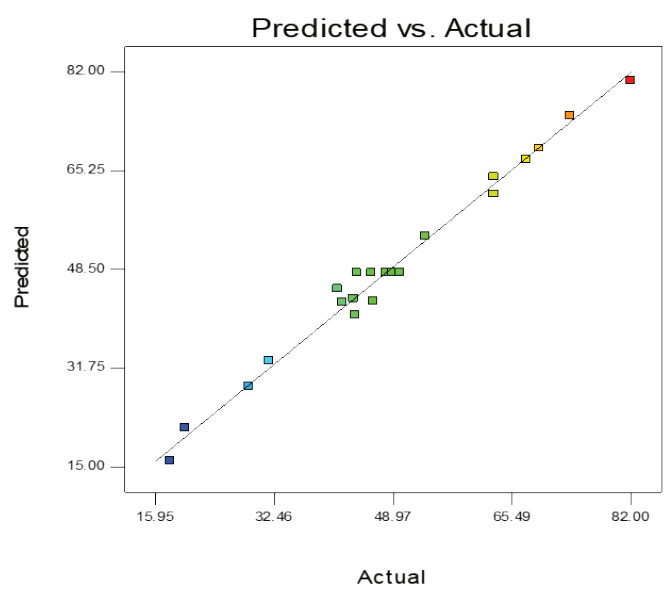

Figure 1 Probability plot of the effects

the relationship between the two. The mathematical model was as follows:

$(\text { Recovery })^{0.81}=+22.87-1.01 * \mathrm{~A}-3.76 * \mathrm{~B}+2.98 * \mathrm{C}+2.97 * \mathrm{D}$

$-2.64 * \mathrm{AB}+2.58 * \mathrm{AC}-3.35 * \mathrm{AD}-1.56 * \mathrm{BC}+1.09 * \mathrm{~A}^{2}-1.79 * \mathrm{C}^{2}$ $+1.01 * \mathrm{D}^{2}$

This equation represents the relationship that diazinon recovery $(\mathrm{R})$ has with the volume of the disperser solvent (A), salt concentration (B), surfactant concentration (C), the volume of extraction solvent (D), and their combinations $(\mathrm{AB}, \mathrm{AC}, \mathrm{AD}$, and $\mathrm{BC})$. Table 5 shows the results of the analysis of variance (ANOVA) for the CCD model and the significance of each coefficient determined by F-values (variation of data about mean value) and P-values (probability). The model turned out to be highly predictive of the experimental results. Extraction solvent volume had a high linear and quadratic effect on response. In addition, the interaction effects of combined variables were significant. The correctness of the model was also ensured by multiple correlation coefficient $\left(\mathrm{R}^{2}\right)$, which was 0.9872 and showed high prediction of the actual value and excellent response, with $0.85 \%$ of the total variation. The predicted $\mathrm{R}^{2}(0.8624)$ was in reasonable agreement with the adjusted $\mathrm{R}^{2}(0.9716)$. Furthermore, the coefficient of variance $(\mathrm{CV}=4.76 \%)$ was low, which indicates significant precision and reliability of the experimental data.

For precision to be adequate, the signal-to-noise ratio should be $>4$. With our model it was 30.73 , indicating that it could be used to evaluate experiments.

Figure 2 shows a 3D response surface diagram of the effects of two factors on diazinon recovery. Figure 2A shows significant interactions of extraction and disperser solvent volume with diazinon recovery $(\mathrm{p}<0.0002)$. Diazinon recovery increased with the increase in extraction solvent volume (from 300 to $450 \mu \mathrm{L}$ ) and disperser solvent volume (from 400 to $800 \mu \mathrm{L}$ ). Significant increase in diazinon

Table 4 Experimental conditions according to the central composite design and observed response values

\begin{tabular}{lcccccc}
\hline Experiment No. & $\begin{array}{c}\text { Methanol volume } \\
(\boldsymbol{\mu} \mathbf{L})\end{array}$ & $\begin{array}{c}\text { NaCl conc. } \\
(\mathbf{\%} \mathbf{w})\end{array}$ & $\begin{array}{c}\text { SLS conc. } \\
(\mathbf{\%} \mathbf{w} \mathbf{v})\end{array}$ & $\begin{array}{c}\text { Toluene volume } \\
(\boldsymbol{\mu L})\end{array}$ & $\begin{array}{c}\text { Actual } \\
\text { recovery }\end{array}$ & $\begin{array}{c}\text { Predicted } \\
\text { recovery }\end{array}$ \\
\hline 1 & 800 & 3.00 & 3.00 & 300.00 & 43.70 & 40.72 \\
\hline 2 & 800 & 3.00 & 1.00 & 300.00 & 20.10 & 21.55 \\
\hline 3 & 800 & 1.00 & 3.00 & 450.00 & 82.00 & 80.49 \\
\hline 4 & 400 & 3.00 & 1.00 & 450.00 & 69.27 & 68.99 \\
\hline 5 & 800 & 1.00 & 1.00 & 450.00 & 43.52 & 43.50 \\
\hline 6 & 400 & 1.00 & 3.00 & 300.00 & 46.3 & 43.06 \\
\hline 7 & 400 & 3.00 & 3.00 & 450.00 & 63.00 & 61.23 \\
\hline 8 & 400 & 1.00 & 1.00 & 300.00 & 31.80 & 32.99 \\
\hline 9 & 200 & 2.00 & 2.00 & 375.00 & 63.00 & 64.14 \\
\hline 10 & 1000 & 2.00 & 2.00 & 375.00 & 53.50 & 54.13 \\
\hline 11 & 600 & 0.00 & 2.00 & 375.00 & 67.50 & 67.14 \\
\hline 12 & 600 & 4.00 & 2.00 & 375.00 & 29.00 & 28.64 \\
\hline 13 & 600 & 2.00 & 0.00 & 375.00 & 18.02 & 15.94 \\
\hline 14 & 600 & 2.00 & 4.00 & 375.00 & 41.33 & 45.18 \\
\hline 15 & 600 & 2.00 & 2.00 & 225.00 & 42.00 & 42.88 \\
\hline 16 & 600 & 2.00 & 2.00 & 525.00 & 73.60 & 74.48 \\
\hline 17 & 600 & 2.00 & 2.00 & 375.00 & 48.00 & 47.89 \\
\hline 18 & 600 & 2.00 & 2.00 & 375.00 & 46.00 & 47.89 \\
\hline 21 & 600 & 2.00 & 2.00 & 375.00 & 49.00 & 47.89 \\
\hline 55 & 600 & 2.00 & 2.00 & 375.00 & 50.00 & 47.89 \\
\hline 19 & 600 & 2.00 & 2.00 & 375.00 & 44.00 & 47.89 \\
\hline
\end{tabular}

SLS - sodium lauryl sulphate 

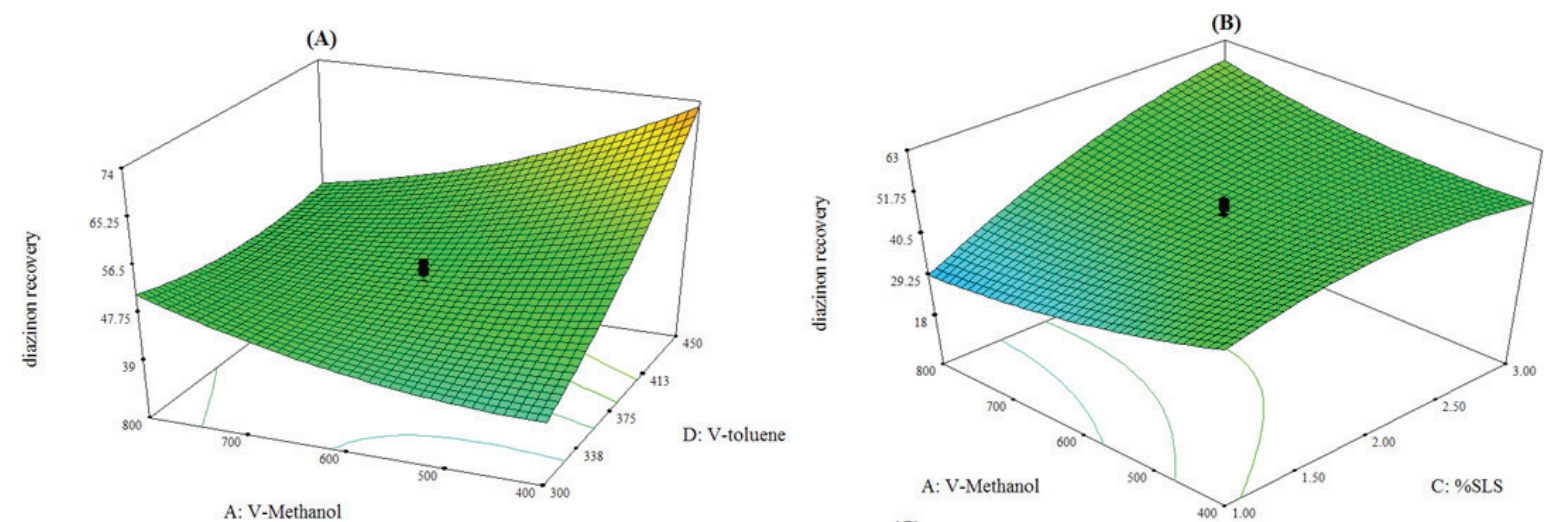

A: V-Methanol

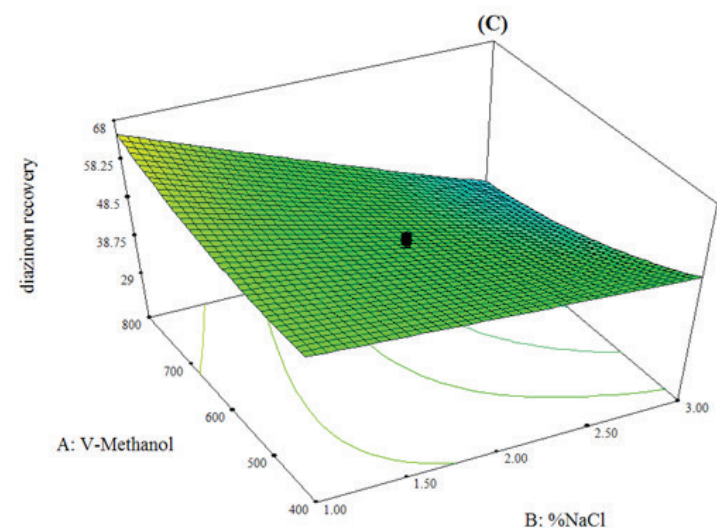

Figure 2 Surface plots showing the effects of variables with the highest impact on the recovery of the method

(A) The effect of the volume of toluene and methanol; (B) the effect of the volume of methanol and the sodium lauryl sulphate (SLS) concentration; $(\mathrm{C})$ the effect of methanol volume and the sodium chloride $(\mathrm{NaCl})$ concentration

Table 5 Analysis of variance for central composite design

\begin{tabular}{lccccc} 
Source & Sum of squares & df & Mean square & F value & $\begin{array}{c}\text { p-value* } \\
\text { Prob. }>\text { F }\end{array}$ \\
\hline Model & 840.2 & 11 & 76.37 & 63.10 & $<0.0001$ \\
\hline A & 16.28 & 1 & 16.28 & 13.45 & 0.0052 \\
\hline B & 112.89 & 1 & 112.89 & 93.28 & $<0.0001$ \\
\hline C & 142.35 & 1 & 142.35 & 117.63 & $<0.0001$ \\
\hline $\mathrm{D}$ & 70.52 & 1 & 70.52 & 58.27 & $<0.0001$ \\
\hline $\mathrm{AB}$ & 27.88 & 1 & 27.88 & 23.04 & 0.0010 \\
\hline $\mathrm{AC}$ & 53.21 & 1 & 53.21 & 43.97 & $<0.0001$ \\
\hline $\mathrm{AD}$ & 44.91 & 1 & 44.91 & 37.11 & 0.0002 \\
\hline $\mathrm{BC}$ & 19.36 & 1 & 19.36 & 16.00 & 0.0031 \\
\hline $\mathrm{A}^{\wedge} 2$ & 31.00 & 1 & 31.00 & 25.62 & 0.0007 \\
\hline $\mathrm{C}^{\wedge} 2$ & 84.41 & 1 & 84.41 & 69.75 & $<0.0001$ \\
\hline $\mathrm{D}^{\wedge} 2$ & 26.72 & 1 & 26.72 & 22.08 & 0.0011 \\
\hline Residual & 10.89 & 9 & 1.21 & & 0.3196 \\
\hline Lack of Fit & 7.37 & 5 & 1.47 & 1.67 & \\
\hline Pure Error & 3.53 & 4 & 0.88 & & \\
\hline Cor Total & 850.91 & 20 & & & \\
\hline
\end{tabular}

* all p-values are statistically significant 
recovery was noted when the extraction solvent volume reached $310 \mu \mathrm{L}$ and disperser solvent $800 \mu \mathrm{L}$.

Figure 2B shows that the interactions between diazinon recovery and disperser solvent volume and surfactant concentrations were significant $(p<0.0001)$ at maximum surfactant concentration of $3 \%$ and maximum disperser solvent volume.

Figure $2 \mathrm{C}$, in turn, shows that diazinon recovery also had significant interactions with disperser solvent volume when it reached its maximum volume of $800 \mu \mathrm{L}$ and when salt percentage was at its lowest $(\mathrm{p}<0.001)$.

\section{Results of method validation}

Standard calibration curves for diazinon were linear with the concentration range of $0.5-4 \mu \mathrm{g} / \mathrm{mL}$, yielding a regression equation of $\mathrm{Y}=0.254 \mathrm{X}+0.006$ with a correlation coefficient of 0.993 . This is generally considered evidence of an acceptable fit and good linearity over the concentration range.

The method yielded LOD and LOQ of $0.15 \mu \mathrm{g} / \mathrm{mL}$ and $0.45 \mu \mathrm{g} / \mathrm{mL}$, respectively, and its precision met the acceptance criteria (Table 6). The intra- and inter- day RSD values did not exceed $5 \%$ (bias interval between 3.0 and $5.0 \%$ ), which indicates that the method is accurate, reliable, and reproducible.
Table 6 also shows that the recovery percentages comply with the acceptance criteria (25).

The specificity of the method was tested with peak purity on blank and spiked urine samples. Blank samples showed no interference when diazinon and IS were added. Under optimised conditions, the separation of diazinon and pirimiphos-methyl was complete (Figure 3).

\section{Method application in real conditions}

The applicability of the proposed DLLME-HPLC-DAD method was evaluated in undiluted urine samples collected from patients poisoned with diazinon who were receiving hospital treatment (Sanandaj, Iran). Relative diazinon recoveries were determined at the spiking level of $0.5,1$, and $3 \mu \mathrm{g} / \mathrm{mL}$. The results of six replicate experiments of each sample were in the range of 75-95.6\%. Therefore, the proposed method can be applied for determining diazinon in human urine samples.

\section{Comparison of the DLLME-HPLC-DAD with other methods}

Table 7 summarises a comparison of the proposed DLLME-HPLC-DAD method with other methods and shows that its LOD, $\mathrm{R}^{2}$, and recovery are well within acceptable ranges.

Table 6 Method precision and accuracy (intra-day: $n=5$; inter-day: $n=5$ series per day, 3 days).

\begin{tabular}{lcccccc}
\hline $\begin{array}{l}\text { Diazinon } \\
\text { concentration } \\
(\boldsymbol{\mu g} / \mathbf{m L})\end{array}$ & Mean \pm SD & $\mathbf{C V}(\mathbf{\%})$ & $\begin{array}{c}\text { Recovery } \pm \text { SD } \\
(\%)\end{array}$ & Mean \pm SD & CV (\%) & $\begin{array}{c}\text { Recovery } \pm \text { SD } \\
(\%)\end{array}$ \\
\cline { 2 - 7 } & $0.46 \pm 0.04$ & 7.4 & $92.1 \pm 1.0$ & $0.48 \pm 0.03$ & 6.9 & $95.6 \pm 1.0$ \\
\hline 0.5 & $0.76 \pm 0.02$ & 3.3 & $76.0 \pm 2.0$ & $0.75 \pm 0.01$ & 1.2 & $75.0 \pm 1.1$ \\
\hline 3 & $2.33 \pm 0.09$ & 4.0 & $77.4 \pm 0.9$ & $2.31 \pm 0.11$ & 4.9 & $77.1 \pm 1.4$ \\
\hline
\end{tabular}

Table 7 Comparison of the proposed DLLME-HPLC-DAD with other analytical methods for determination of diazinon in biological samples

\begin{tabular}{|c|c|c|c|c|c|}
\hline Method & Matrix & $\begin{array}{c}\text { LOD } \\
(\mu \mathrm{g} / \mathrm{mL})\end{array}$ & $\begin{array}{c}\text { Correlation } \\
\text { coefficient }\left(\mathbf{R}^{2}\right)\end{array}$ & Recovery (\%) & Ref. No. \\
\hline SPE-GC-MS & whole blood & 0.15 & 0.9981 & $78-87$ & 15 \\
\hline SPE-HPLC-DAD & plasma & 0.15 & 0.998 & $77.7-86.3$ & 17 \\
\hline LLE-HPLC-DAD & $\begin{array}{l}\text { whole blood, } \\
\text { serum, urine }\end{array}$ & 0.78 & 0.9996 & $\begin{array}{c}\text { 97.4-99.01 } \\
\text { (for blood and serum) } \\
101.1-101.4 \text { (for urine) }\end{array}$ & 16 \\
\hline mini-QuEChERS-LC-MS-MS & $\begin{array}{l}\text { whole blood, } \\
\text { gastric content }\end{array}$ & 0.1 & 0.95 & $80-100$ & 18 \\
\hline MEPS-GC-MS-MS & whole blood & 0.5 & 0.99 & $61-77$ & 26 \\
\hline DBS-GC-MS-MS & whole blood & 0.05 & 0.998 & $4.56-5.11$ & 27 \\
\hline DLLME-HPLC-DAD & urine & 0.15 & 0.993 & $75.0-95.6$ & this study \\
\hline
\end{tabular}

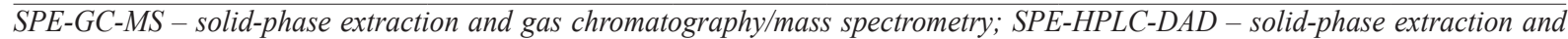
high-performance liquid chromatography (HPLC) with diode array detector (DAD); LLE-HPLC-DAD-liquid-liquid extraction and high-performance liquid chromatography (HPLC) with diode array detector; mini-QuEChERS-LC-MS-MS - modified quick, easy, cheap, effective, rugged and safe (QuEChERS) method - liquid chromatography with tandem mass spectrometry; MEPS-GC-MS-MS - microextraction by packed sorbent (MEPS) - gas chromatography-tandem mass spectrometry; DBS-GC-MS-MS - dried blood spot (DBS) - gas chromatography coupled to tandem mass spectrometry; DLLME-HPLC-DAD - dispersive liquid-liquid phase microextraction-high performance liquid chromatography with diode array detector 


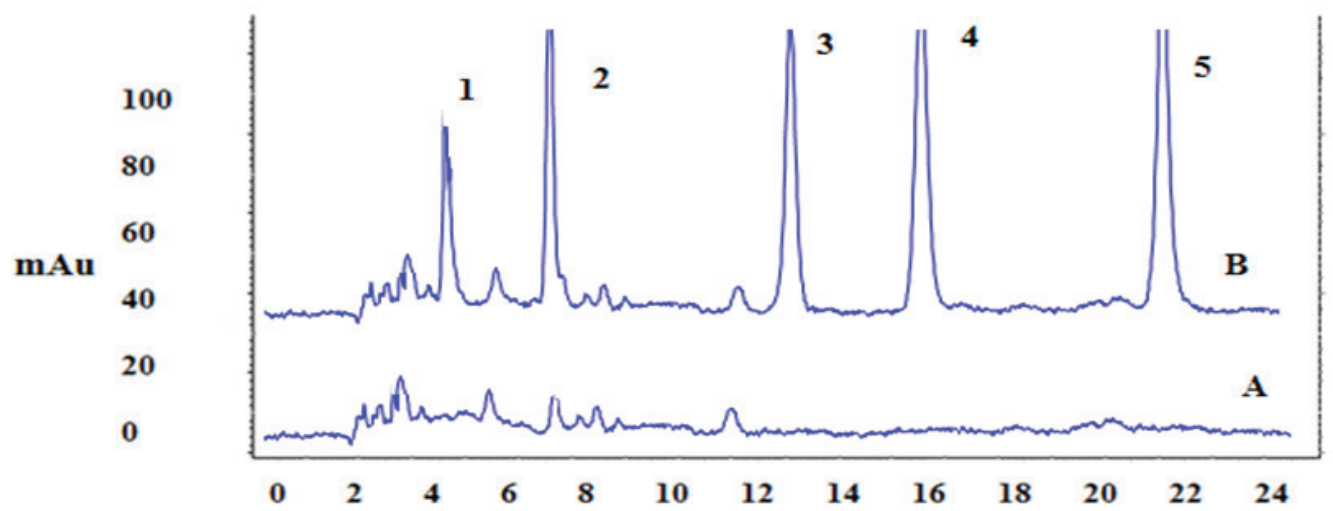

Minutes

Figure 3 Specificity of the proposed method for the analysis of diazinon in urine sample Chromatogram A: blank urine; Chromatogram B: urine spiked with: 1 - tramadol, 2 - azinphos-ethyl, 3 - diazinon, 4 - pirimiphosmethyl, and 5 - chlorpyrifos

\section{CONCLUSION}

Our findings evidence that our DLLME-HPLC-DAD is a rapid and simple extraction and determination method for diazinon in human urine samples. It overcomes the limitations of conventional sample preparation methods that involve the use of large volumes of expensive and toxic organic solvents. However, it is evident that further studies are necessary for different biological specimen in order to suppress matrix effects and enhance extraction recoveries. The proposed DLLME-HPLC-DAD method is simple, cheap, accurate, and sensitive enough to be applied in clinical and forensic toxicological analysis.

\section{Acknowledgments}

This study was part of the PhD thesis of Reza Mohammadzaeri, proposed and approved by the Department of Chemistry, Science and Research Branch, Islamic Azad University, Kerman, Iran. The authors would like to thank the Legal Medicine Center of the province of Kurdistan, Iran for providing financial support to conduct this research (Grant No.1054-125648). The authors also wish to thank Dr Golamreza Homayonpour for his invaluable assistance.

\section{Conflicts of interest}

None to declare.

\section{REFERENCES}

1. Adinew GM, Asrie AB, Birru EM. Pattern of acute organophosphorus poisoning at university of gondar teaching hospital, Northwest Ethiopia. BMC Res Notes 2017;10:149. doi: 10.1186/s13104-017-2464-5
2. Kumar SV, Fareedullah M, Sudhakar Y, Venkateswarlu Kumar EA. Current review on organophosphorus poisoning. Arch Appl Sci Res 2010;2:199-215.

3. Soltaninejad K, Shadnia S. History of the use and epidemiology of organophosphorus poisoning. In: BalaliMood M, Abdollahi M, editors. Basic and clinical toxicology of organophosphoours compounds. $1^{\text {st }}$ ed. London: SpringerVerlag; 2014. p. 25-43.

4. Eddleston M, Buckley NA, Eyer P, Dawson A. Management of acute organophosphorus pesticide poisoning. Lancet 2008;371:597-607. doi: 10.1016/S0140-6736(07)61202-1

5. Çolak Ş, Erdoğan MÖ, Baydin A, Afacan MA, Kati C, Duran L. Epidemiology of organophosphate intoxication and predictors of intermediate syndrome. Turk J Med Sci 2014;44:279-82. doi: 10.3906/sag-1211-31

6. Ram P, Kanchan T, Unnikrishnan B. Pattern of acute poisonings in children below 15 years - a study from Mangalore, South India. J Forensic Leg Med 2014;25:26-9. doi: 10.1016/j.jflm.2014.04.001

7. Kumar MR, Kumar GP, Babu PR, Kumar SS, Subrahmanyam BV, Veeraprasad M, Rammohan P, Srinivas M, Agrawal A. A retrospective analysis of acute organophosphorus poisoning cases admitted to the tertiary care teaching hospital in South India. Ann Afr Med 2014;13:71-5. doi: 10.4103/15963519.129876

8. Liu H, Kan B, Jian X, Zhang W, Zhou Q, Wang J. Parasuicidal poisoning by intramuscular injection of insecticide: A case report. Exp Ther Med 2013;6:696-8. doi: 10.3892/ etm.2013.1216

9. Kanchan T, Menezes RG, Kumar TS, Bakkannavar SM, Bukelo MJ, Sharma PS, Rasquinha JM, Shetty BS. Toxicoepidemiology of fatal poisonings in Southern India. J Forensic Leg Med 2010;17:344-7. doi: 10.1016/j. jflm.2010.05.006

10. Raina S, Mahesh DM, Sood V, Kaushal SS, Gupta D. Self injection of Dichlorvos, an organophosphorus compound. Online J Health Allied Scs 2008;7:1-3. 
11. Pandit V, Seshadri S, Rao SN, Samarasinghe C, Kumar A, Valsalan R. A case of organophosphate poisoning presenting with seizure and unavailable history of parenteral suicide attempt. Emerg Trauma Shock 2011;4:132-4. doi: 10.4103/0974-2700.76825

12. National Pesticide Information Center. Diazinon Fact Sheet [displayed 25 August 2018]. Available at http://www.npic. orst.edu/factsheets/diazinontech.pdf

13. US Environmental Protection Agency. Diazinon: Phase out of all residential uses of the insecticide [displayed 25 August 2018]. Available at http://www.epa.gov/pesticides/factsheets/ chemicals/diazinon-factsheet.htm

14. Soltaninejad K, Faryadi M, Sardari F. Acute pesticide poisoning related deaths in Tehran during the period 20032004. J Forensic Leg Med 2007;14:352-4. doi: 10.1016/j. jflm.2006.12.011

15. Park MJ, In SW, Lee SK, Choi WK, Park YS, Chung HS. Postmortem blood concentrations of organophosphorus pesticides. Forensic Sci Int 2009;184:28-31. doi: 10.1016/j. forsciint.2008.11.008

16. Cho Y, Matsuoka N, Kamiya A. Determination of organophosphorous pesticides in biological samples of acute poisoning by HPLC with diode-array detector. Chem Pharm Bull 1997;45:737-40. doi: 10.1248/cpb.45.737

17. Abu-Qare AW, Abou-Donia MB. Determination of diazinon, chlorpyrifos, and their metabolites in rat plasma and urine by high-performance liquid chromatography. J Chromtogr Sci 2001;39:200-4. doi: 10.1093/chromsci/39.5.200

18. Kim HS, Kim J, Suh JH, Han SB. General unknown screening for pesticides in whole blood and Korean gastric contents by liquid chromatography-tandem mass spectrometry. Arch Pharm Res 2014;37:1317-24. doi: 10.1007/s12272-0140440-3

19. Sarafraz-Yazdi A, Amiri A. Liquid-phase microextraction. Trends Anal Chem 2010;29:1-14. doi: 10.1016/j. trac.2009.10.003
20. Rezaee M, Assadi Y, Milani Hosseini MR, Aghaee E, Ahmadi F, Berijani S. Determination of organic compounds in water using dispersive liquid-liquid microextraction. J Chromatogr A 2006;1116(1):1-9. doi: 10.1016/j.chroma.2006.03.007

21. Al-Saidi HM, Emara AAA. The recent developments in dispersive liquid-liquid microextraction for preconcentration and determination of inorganic analytes. J Saudi Chem Soci 2014;18:745-61. doi: 10.1016/j.jscs.2011.11.005

22. Habibi H, Mohammadi A, Kamankesh M. Application and optimization of dispersive liquid-liquid microextraction coupled with high-performance liquid chromatography for sensitive determination of furfural and hydroxymethyl furfural in jarred and canned baby-foods. Nutr Food Sci Res 2017:4:25-32. doi: 10.18869/acadpub.nfsr.4.1.25

23. Bro R. Multivariate calibration. What is in chemometrics for the analytical chemist? Anal Chim Acta 2003;500:185-94. doi: 10.1016/S0003-2670(03)00681-0

24. Singh G, Pai RS. Optimization (Central Composite Design) and validation of HPLC method for investigation of emtricitabine loaded Poly(lactic-co-glycolic acid) nanoparticles: In vitro drug release and in vivo pharmacokinetic studies. Sci World J 2014:583090. doi: 10.1155/2014/583090

25. Shah VP, Midha KK, Findlay JW, Hill HM, Hulse JD, McGilveray IJ, McKay G, Miller KJ, Patnaik RN, Powell ML, Tonelli A, Viswanathan CT, Yacobi A. Bioanalytical method validation - a revisit with a decade of progress. Pharm Res 2000;17:1551-7. doi: 10.1023/a:1007669411738

26. Santos C, Oppolzer D, Gonçalves A, Barroso M, Gallardo E. Determination of organophosphorous pesticides in blood using microextraction in packed sorbent and gas chromatography - tandem mass spectrometry. J Anal Toxicol 2018;42:321-9. doi: 10.1093/jat/bky004

27. Soares S, Castro T, Rosado T, Fernández N, Barroso M, Gallardo E. New analytical approach to determine organophosphorus insecticides in blood by dried matrix spots sampling and GC-MS/MS. Anal Bioanal Chem 2018;410:7955-64. doi: 10.1007/s00216-018-1417-8

\section{Disperzivna tekućinsko-tekućinska mikroekstrakcija temeljena na eksperimentalnom centralnom kompozitnom dizajnu u svrhu određivanja diazinona u ljudskoj mokraći: razvoj i validacija metode}

Trovanje diazinonom važan je problem za medicinu rada te kliničku i forenzičnu toksikološku praksu. Premda su postojeće metode njegova utvrđivanja u biološkim uzorcima dovoljno osjetljive i specifične, njihova je primjena za rutinske analize preskupa i dugotrajna. Zbog toga je cilj ovoga istraživanja bio razviti i validirati jednostavnu metodu disperzivne tekućinsko-tekućinske mikroekstrakcije (engl. dispersive liquid-liquid microextraction, krat. DLLME) kojom bi se uzorci ljudske mokraće pripremili za analizu diazinona tekućinskom kromatografijom visoke djelotvornosti s detektorom s nizom fotodioda (engl. high performance liquid chromatography with diode-array detector, krat. HPLC-DAD) radi utvrđivanja izloženosti i trovanja diazinonom. U tu smo svrhu u preliminarnim eksperimentima prvo odredili ključne parametre: vrstu i volumen ekstrakcijskoga i disperzijskoga otapala, $\mathrm{pH}$, površinski aktivne tvari (surfaktanta) te koncentraciju soli. Zatim smo s pomoću eksperimentalnoga centralnoga kompozitnoga dizajna utvrdili optimalne eksperimentalne uvjete za $D L L M E-H P L C-D A D$. Za DLLME oni su bili $800 \mu \mathrm{L}$ metanola (kao disperzijskoga otapala) te $310 \mu \mathrm{L}$ toluena (kao ekstrakcijskoga otapala) za brzu injekciju uzorka mokraće. Uzorak je injektiran u HPLC-DAD (5-mikrometarski analitički stupac C18, 250×4,6 mm), a mobilna je faza bila mješavina acetonitrila i pufera (63:37 v/v, pH 3.2; protok: $1 \mathrm{~mL} / \mathrm{min})$. Standardne su kalibracijske krivulje za diazinon bile linearne s rasponom koncentracija diazinona od 0,5 do $4 \mu \mathrm{g} / \mathrm{mL}$, a regresijska jednadžba $\mathrm{Y}=0,254 \mathrm{X}+0,006$ s koeficijentom korelacije 0,993 . Granice detekcije odnosno kvantifikacije diazinona bile su $0,15 \mu \mathrm{g} / \mathrm{mL}$ odnosno $0,45 \mu \mathrm{g} / \mathrm{mL}$. Ova se metoda pokazala točnom, preciznom, osjetljivom i linearnom u širokom rasponu koncentracija diazinona u uzorcima mokraće, stoga se može koristiti za njegovu rutinsku analizu u kliničkoj i forenzičnoj toksikološkoj praksi.

KLJUČNE RIJEČI: disperzijsko otapalo; ekstrakcijsko otapalo; mikroekstrakcija tekućinskom fazom; tekućinska kromatografija visoke djelotvornosti; Taguchijev ortogonalni niz 